Article

\title{
How Do Novel M-Rootstock (Vitis Spp.) Genotypes Cope with Drought?
}

\author{
Davide Bianchi, Leila Caramanico, Daniele Grossi, Lucio Brancadoro * and \\ Gabriella De Lorenzis * \\ Dipartimento di Scienze Agrarie ed Ambientali, Università degli Studi di Milano, via Giovanni Celoria 2, \\ 20133 Milano, Italy; davide.bianchi3@unimi.it (D.B.); leila.caramanico@unimi.it (L.C.); \\ grossi.lele@gmail.com (D.G.) \\ * Correspondence: lucio.brancadoro@unimi.it (L.B.); gabriella.delorenzis@unimi.it (G.D.L.); \\ Tel.: +39-02-503-16559 (L.B.); +39-02-503-16565 (G.D.L.)
}

Received: 3 September 2020; Accepted: 14 October 2020; Published: 17 October 2020

check for updates

\begin{abstract}
Most of the vineyards around the world are in areas characterized by seasonal drought, where water deficits and high temperatures represent severe constraints on the regular grapevine growth cycle. Although grapevines are well adapted to arid and semi-arid environments, water stress can cause physiological changes, from mild to irreversible. Screening of available Vitis spp. genetic diversity for new rootstock breeding programs has been proposed as a way for which new viticulture challenges may be faced. In 2014, novel genotypes (M-rootstocks) were released from the University of Milan. In this work, the behavior of M1, M3 and M4 in response to decreasing water availabilities ( $80 \%, 50 \%$ and $20 \%$ soil water content, SWC) was investigated the physiological and gene expression levels, evaluating gas exchange, stem water potential and transcript abundances of key genes related to ABA (abscisic acid) biosynthesis (VvZEP, VvNCED1 and VvNCED2) and signaling ( $V v P P 2 C 4, V v S n R K 2.6$ and $V v A B F 2$ ), and comparing them to those of cuttings of nine commercial rootstocks widely used in viticulture. M-rootstocks showed a change at physiological levels in severe water-stressed conditions ( $20 \%$ soil water content, SWC), reducing the stomatal conductance and stem water potential, but maintaining high photosynthetic activity. Water use efficiency was high in water-limiting conditions. The transcriptional changes were observed at 50\% SWC, with an increment of transcripts of $V v N C E D 1$ and $V v N C E D 2$ genes. M-rootstocks showed similar behavior to 1103P and 110R rootstocks, two highly tolerant commercial genotypes. These rootstocks adopted a tolerant strategy to face water-stressed conditions.
\end{abstract}

Keywords: ABA biosynthesis; ABA signaling; photosynthetic activity; stem water potential; stomatal conductance; transpiration; water use efficiency

\section{Introduction}

Grapevine (Vitis vinifera L.) is one of the most widely cultivated and prized fruit crops around the world. In arid and semi-arid environments, the vines undergo a slow decrease in water availability during the growing season [1]. Traditionally, grapevine is a non-irrigated crop due to the adaptation to water limited conditions, though severe water stress causes minor to irreversible physiological and biochemical changes [2,3].

World viticulture is characterized by the use of $V$. vinifera varieties grafted onto a rootstock (Vitis spp.) due to the arrival of phylloxera (Daktulosphaira vitifoliae (Fitch)), a severe threat for grapevine survival, which was accidentally imported into Europe from North America [4]. North American Vitis species are able to resist to phylloxera due to having co-evolved with the pathogen, therefore they are utilized as rootstocks, as single or inter-specific hybrids. Rootstocks also contribute to the 
control of other soil-borne pests such as nematodes, as well as various abiotic constraints, such as drought, salinity, lime-rich soils and deficient mineral nutrition [5-8]. They also modify whole plant development, biomass accumulation and phenology [9].

The Mediterranean basin is considered one of the most vulnerable regions of the world to climate change and will potentially have to deal with water scarcity and soil erosion in the next few years $[10,11]$. Its climate is characterized by infrequent rainfall (less than 100 days per year) that is unevenly distributed over time (long periods of summer drought) and sometimes quite sparse (about 300 to $500 \mathrm{~mm}$ per year in some semi-arid regions). Most climate change scenarios for this area predict a decrease in rainfall and higher temperatures. IPCC (Intergovernmental Panel on Climate Change) forecasts indicate a yearly temperature increase between $2{ }^{\circ} \mathrm{C}$ and $4{ }^{\circ} \mathrm{C}$ and a decrease in rainfall between $4 \%$ and $30 \%$ by 2050 [12]. Due to their perennial status, grapevines will be highly vulnerable to environmental changes, representing a substantial risk for viticulture [13].

Water flows into the plant in a soil-plant-atmosphere continuum [14]. The whole water transport system in the plant is influenced by the anatomical structure of xylem vessels [15], hydraulic constraints [16] and chemical signals [17,18]. When soil water availability decreases, one of the earliest responses is stomatal closure, in order to maintain a favorable water balance, buffering the drop in xylem water potential and avoiding embolisms $[19,20]$. The closure of guard cells leads to a reduction of $\mathrm{CO}_{2}$ assimilation and $\mathrm{H}_{2} \mathrm{O}$ transpiration from leaves and, consequently, the photosynthetic activity decreases sharply [21].

One of the factors inducing stomatal closure is abscisic acid (ABA), a hormone produced by roots and leaves [22-30]. ABA accumulates in the plant when soil dries out and water potential drops [22], the synthesis of which is entrusted to a minor branch of the carotenoid pathway. The early steps of ABA biosynthesis are catalyzed by zeaxanthin epoxidase (ZEP) and 9-cis-epoxycarotenoid dioxygenase (NCED) enzymes [31]. VvZEP and VvNCED gene expression is strongly induced by water stress [32-34] and salt stress [35]. This hormone, through the xylem sap, reaches guard cells, enhancing the content of reactive oxygen species ( $\mathrm{ROS}$, especially $\mathrm{H}_{2} \mathrm{O}_{2}$ ). Stopping the influx and promoting the efflux of potassium ions $(\mathrm{K}+)$ results in a rise in calcium ions $\left(\mathrm{Ca}^{2+}\right)$ in the cytosol and, consequently, cells lose their turgor. The ABA signaling pathway is mediated by three main components: (i) pyrabactin resistance1/pyr1-like/regulatory components of ABA receptors (PYR/PYL/RCAR family of ABA receptors); (ii) ABA-regulated protein phosphatase 2Cs (PP2CAs); (iii) ABA-regulated SNRK2 protein kinase (SnPK2) [36,37]. Without stimuli, the ABA receptor is an unliganded form and the protein kinase is bound to the protein phosphatase. Specific receptors (PYR/PYL/RCARs) bind to ABA when its concentration increases and the hormone-receptor complex becomes an active site for the protein PP2C. The activated receptor binds to PP2C and frees SnPK2, which in turn is phosphorylated by another protein kinase. Multiple step phosphorylation of SnRK2 activates ABRE-binding protein (ABRB)/ABRE-binding factor (ABF) which induces many ABA-responsive gene expression [38].

In grapevine, the expression of $V v N C E D 1, V v N C E D 2$ and $V v Z E P$ genes has been directly correlated with ABA accumulation in response to water stress [33,34,39] and their expression was suggested as marker of ABA biosynthesis [40]. The expression of genes involved in the ABA signaling pathway revealed that the genes coding for RCAR, SnRK and ABF are downregulated in drought conditions, while VvPP2C genes are generally upregulated [40,41].

In the context of global warming, the exploitation of grapevine genetic diversity and the better understanding of plant responses to environmental stresses represent the way in which new viticultural challenges may be faced [42-44]. Although a significant number of efforts in grapevine rootstock selection have been carried out to date, fewer than 10 rootstocks are widely used in viticulture, with a negative impact on the grapevine response to biotic and abiotic stresses [9,45]. Since 1985, the Department of Agricultural and Environmental Sciences (DiSAA) research group operating at the University of Milan has been working on the selection of new rootstocks able to cope with abiotic stresses [5]. Some genotypes (series "M": M1, M2, M3 and M4) were selected and released in 2014 and registered in the National Register of Vine Varieties (RNVV). M1 and M3 exhibit tolerance to iron-limited conditions 
(M1 > M3) [8,46], M2 and M4 display moderate resistance to salinity (Porro et al., 2013; Meggio et al., 2014) and M4 shows high tolerance to drought (Porro et al., 2013; Meggio et al., 2014; Corso et al., 2015).

To assess the drought tolerance of M-rootstocks in comparison to other commercial genotypes largely used in viticulture, physiological (gas exchange and stem water potential) and transcriptomic performances (genes involved in ABA synthesis and ABA-mediated responses to drought) were evaluated under well-watered and water-stressed conditions.

\section{Results}

\subsection{The Physiological Response of Grapevine Rootstocks to Drought}

The physiological parameters of photosynthesis (Pn), stomatal conductance (Gs), transpiration (E) and stem water potential $\left(\Psi_{\mathrm{S}}\right)$ were evaluated in 12 own-rooted grapevine rootstocks under decreasing water availability (from 80 to $20 \%$ soil water content, SWC) (Table 1, Table S1).

Table 1. List of 12 grapevine rootstocks subjected to water limitation and information about their pedigree (based on Migliaro et al. [43]).

\begin{tabular}{cc}
\hline Rootstock & Pedigree \\
\hline $1103 \mathrm{P}$ & V. berlandieri cv. Resseguier $\mathrm{nr} .2 \times$ V. rupestris cv. Du Lot \\
$110 \mathrm{R}$ & V. berlandieri $\mathrm{cv}$. Boutin $\times$ V. rupestris cv. Du Lot \\
$140 \mathrm{Ru}$ & V. berlandieri $\mathrm{cv}$. Boutin $\times$ V. rupestris cv. Du Lot \\
161-49C & V. berlandieri $\times$ V. riparia \\
41B & V. vinifera cv. Chasselas $\times$ V. berlandieri cv. Planchon \\
420A & V. berlandieri $\times$ V. riparia \\
K5BB & V. berlandieri Resseguier nr. $2 \times$ V. riparia cv. Gloire de Montpellier \\
M1 & Kober $5 \mathrm{BB} \times$ Teleki $5 \mathrm{C}($ V. berlandieri cv. Planchon $\times$ V. riparia $)$ \\
M3 & Kober $5 \mathrm{BB} \times$ Teleki $5 \mathrm{C}$ \\
M4 & unknown $\times 1103 \mathrm{P}$ \\
Schwarzmann & V. riparia $\times$ V. rupestris \\
SO4 & V. berlandieri cv. Resseguier nr. $2 \times V$. riparia $\mathrm{cv}$. Gloire de Montpellier \\
\hline
\end{tabular}

The physiological activity reported in well-watered conditions ( $80 \%$ SWC) was maintained at $50 \%$ SWC and decreased at $20 \%$ SWC (Figure S1). The water condition showing the most significant differences (20\% SWC) was used to investigate the behavior of each grapevine rootstock under water deficit conditions, in terms of photosynthetic activity and intrinsic water use efficiency (iWUE) (Figure 1). The V. berlandieri $\times$ V. rupestris hybrids (1103P, 110R and 140Ru rootstocks), 41B, M4 and M3 rootstocks carried out high photosynthetic activity under both water conditions, exceeding average levels. The $V$. riparia $\times V$. berlandieri hybrids (161-49C, 420A, K5BB) showed Pn values lower than average values at both water availabilities. The M1 rootstock showed similar Pn values in both conditions, exceeding the average value at $20 \%$ SWC (Figure 1a). Differences between genotypes also occurred when iWUE, calculated as the ratio between Pn and stomatal conductance values, was taken into account: 110R, 140Ru and M1 rootstocks maintained high efficiency when SWC decreased; iWUE values of 161-49C were reduced at 20\% SWC; the 41B, K5BB and SO4 rootstocks reported iWUE values under average levels at $80 \%$ SWC, maintaining the same efficiency at $20 \%$; $1103 \mathrm{P}$, M3 and M4 rootstocks increased their efficiency under the water-stressed condition (Figure 1b). 

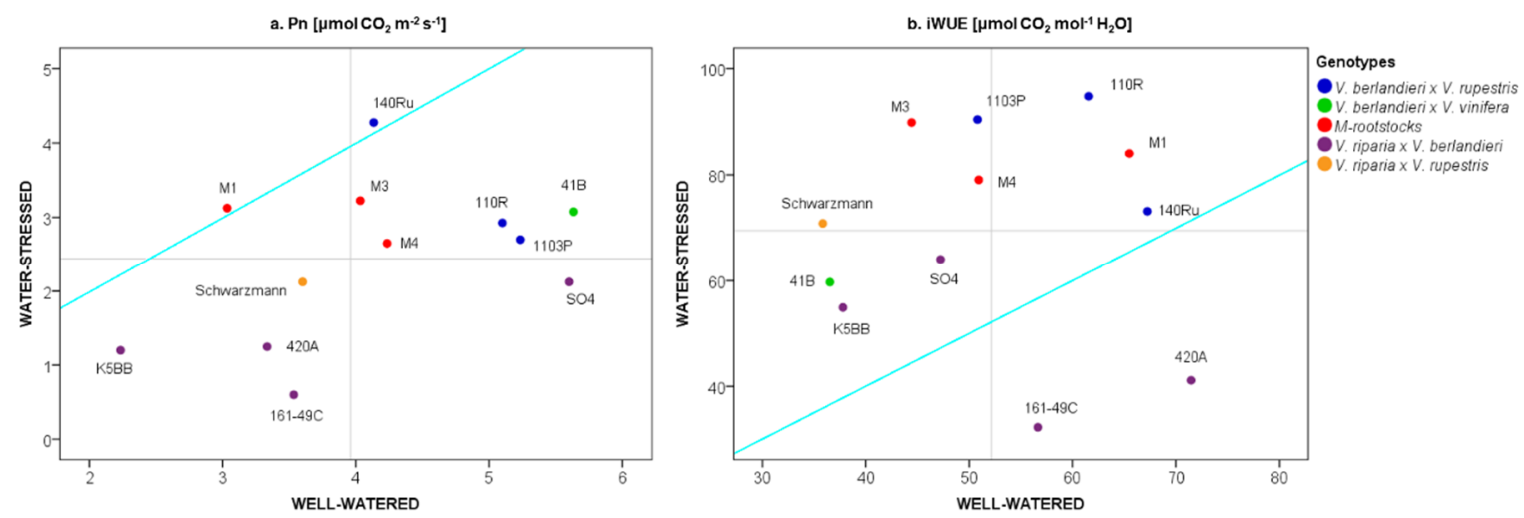

Figure 1. Comparison of performances in 12 own-rooted grapevine rootstocks under both well-watered ( $80 \%$ soil water content, SWC) and water-stressed ( $20 \%$ SWC) conditions in terms of net photosynthesis (Pn) (a) and intrinsic water use efficiency (iWUE) (b). Colors are attributed according to the breeding materials (Table 1). M-rootstock pedigree: M1-K5BB × Teleki 5C; M3-K5BB $\times$ Teleki 5C; M4—unknown $\times 1103$. Lines are set to the mean values of Pn (a) and iWUE (b) for each water condition. Lines 1:1 are reported in cyan.

To investigate rootstock WUE in depth, Pn was analyzed as a function of Gs under the water-stressed condition ( $20 \%$ SWC). Clear differences emerged in the behavior of the 12 genotypes, resulting in three different groups (Figure 2): (i) Group A, genotypes reporting Gs values lower than the water-stressed threshold ( $50 \mathrm{mmol} \mathrm{H}_{2} \mathrm{O} \mathrm{m}^{-2} \mathrm{~s}^{-1}$, based on Cifre et al. [47]) and Pn values higher than the general average value $\left(2.5 \mu \mathrm{mol} \mathrm{CO} \mathrm{m}^{-2} \mathrm{~s}^{-1}\right)$ (1103P, 110R, M1, M3 and M4 rootstocks); (ii) Group $\mathrm{B}$, genotypes reporting Gs values lower than the water-stressed threshold and Pn values lower than the general average value (161-49C, 420A, K5BB, Schwarzmann and SO4 rootstocks); (iii) Group C, genotypes reporting Gs values higher than the water-stressed threshold and Pn values higher than the general average value (140Ru and 41B rootstocks).

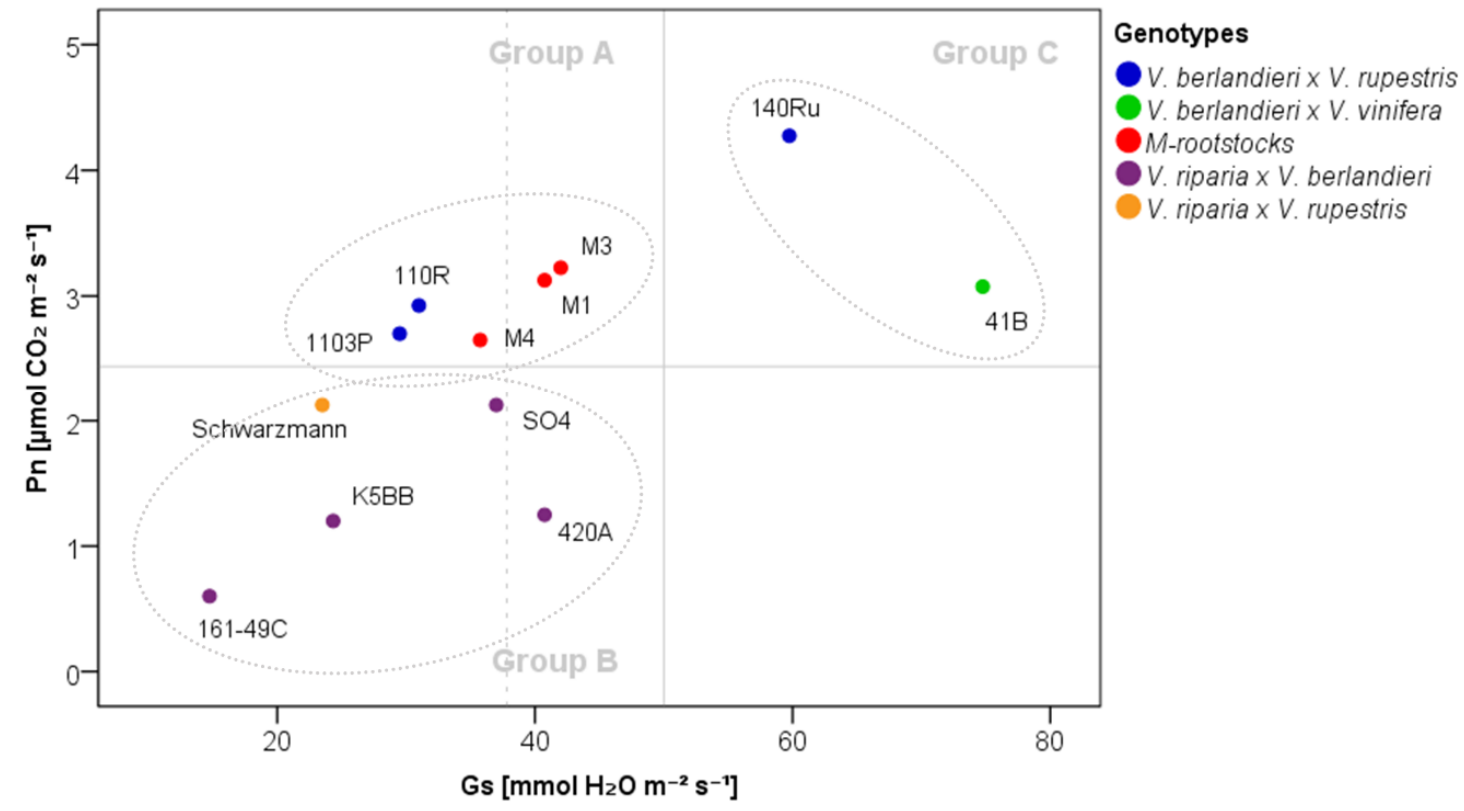

Figure 2. Stomatal conductance (Gs) as function of net photosynthesis (Pn) in 12 own-rooted grapevine rootstocks at and $20 \%$ soil water content (SWC). Colors are attributed according to the breeding materials (Table 1). M-rootstock pedigree: M1—K5BB × Teleki 5C; M3-K5BB $\times$ Teleki 5C; M4—unknown $\times 1103$. Thresholds for group identification were set to $50 \mathrm{mmol} \mathrm{H}_{2} \mathrm{O} \mathrm{m}^{-2} \mathrm{~s}^{-1}$ [47] for Gs and to the average for Pn at $20 \%$ SWC. The dotted line shows the average Gs value at $20 \%$ SWC. 
The three rootstock groups (A, B and C) were compared in term of $\Psi_{\mathrm{S}}$ with the decreasing levels of SWC $(80 \%, 50 \%$ and $20 \%)$. Stem water potential settled at $-0.4 \mathrm{MPa}$ at $80 \%$ and $50 \%$ SWC without showing statistically significant differences among groups. At 20\% SWC, Group A and C rootstocks decreased in $\Psi_{S}$ value, whereas Group B rootstocks maintained higher $\Psi_{S}$ values, without a significant reduction of $\Psi_{S}$ values with respect to $50 \%$ SWC. At $20 \%$ SWC, Group A rootstocks reported $\Psi_{S}$ values lower than Group B rootstocks (Figure 3a). Moreover, the $\Psi_{S}$ was analyzed as a function of stomatal conductance and differences among groups were identified as well (Figure 3b): Group A rootstocks showed, mainly, Gs and $\Psi_{S}$ levels below the stress threshold $\left(50 \mathrm{mmol} \mathrm{H}_{2} \mathrm{O} \mathrm{m}^{-2} \mathrm{~s}^{-1}\right.$, based on Cifre et al. [47]) and average value, respectively; Group B rootstocks showed Gs values below the threshold and, mainly, $\Psi_{\mathrm{S}}$ values above the average value (except for K5BB rootstocks); Group C rootstocks showed Gs values exceeding the stress threshold, whereas the $\Psi_{\mathrm{S}}$ value was higher than the average for 140Ru rootstock and lower than the average for 41B rootstock.
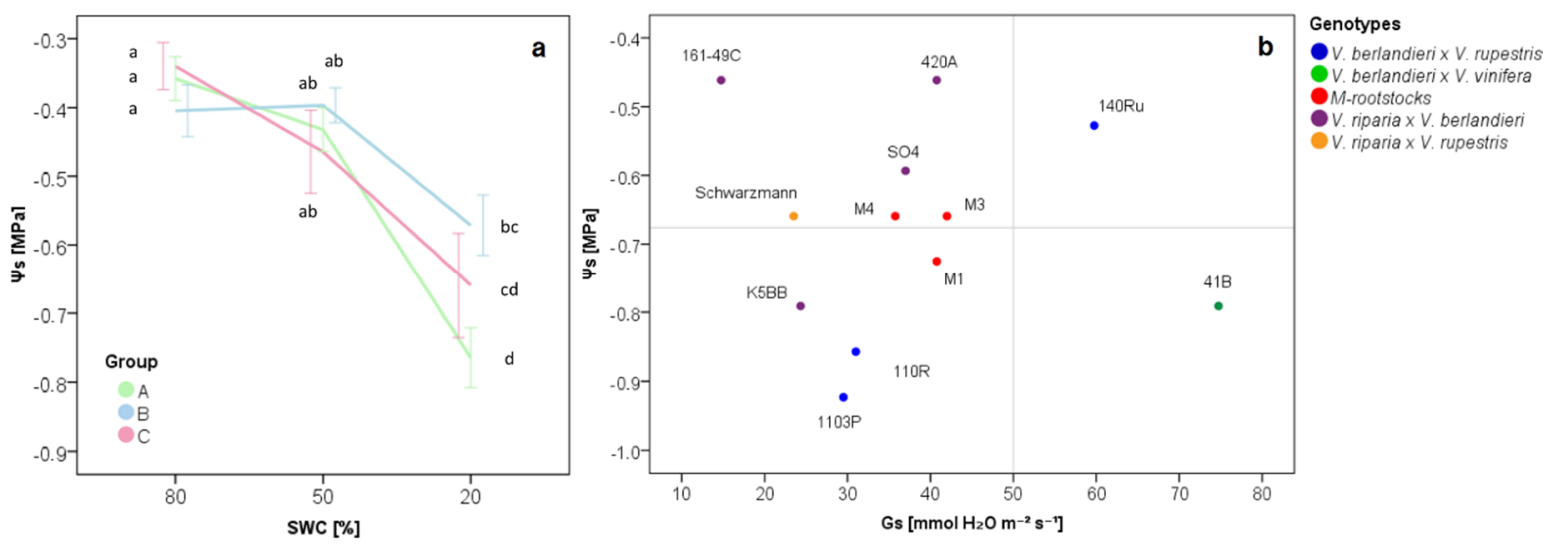

Figure 3. Stem water potential $\left(\Psi_{S}\right)$ as a function of decreasing soil water content (SWC) (a) and stomatal conductance (b). Groups are defined in Figure 2, according to the gas exchange values. Group A: 1103P, 110R, M1, M3 and M4 rootstocks; Group B: 161-49C, 420A, K5BB, Schwarzmann and SO4 rootstocks; Group C: $140 \mathrm{Ru}$ and 41B rootstocks. Letters show the statistical differences defined according to Tukey's post hoc test at a $p$-value of 0.05 . In plot (b), thresholds were set to $50 \mathrm{mmol} \mathrm{H}_{2} \mathrm{O}$ $\mathrm{m}^{-2} \mathrm{~s}^{-1}$ [47] for Gs and to the average for $\Psi_{\mathrm{S}}$ at $20 \%$ SWC.

At $20 \%$ SWC, groups were compared for all physiological parameters and the results are summarized in Table 2. Group B rootstocks significantly differed from Group A and C rootstocks for Pn and $\Psi_{S}$ values, while Group C rootstocks significantly differed from Group A and B rootstocks for Gs and E values.

Table 2. Average value and standard deviation of physiological parameters for grapevine rootstock genotypes of Group A (1103P, 110R, M1, M3 and M4), Group B (161-49C, 420A, K5BB, Schwarzmann and SO4) and Group C (140Ru and 41B) at 20\% soil water content (SWC). Groups are defined in Figure 2, according to the intrinsic water use efficiency. $\mathrm{Pn}=$ net photosynthesis $\left(\mu \mathrm{mol} \mathrm{CO} \mathrm{C} \mathrm{m}^{-2} \mathrm{~s}^{-1}\right)$; $\mathrm{Gs}=$ stomatal conductance $\left(\mathrm{mmol} \mathrm{H}_{2} \mathrm{O} \mathrm{m}^{-2} \mathrm{~s}^{-1}\right) ; \mathrm{E}=$ transpiration $\left(\mathrm{mmol} \mathrm{H}_{2} \mathrm{O} \mathrm{m}^{-2} \mathrm{~s}^{-1}\right) ; \Psi_{\mathrm{S}}=$ stem water potential (MPa). Statistical differences among groups for each parameter are defined according to Tukey's post hoc test at a $p$-value of 0.05 .

\begin{tabular}{cccccccccccccc}
\hline Parameter & \multicolumn{3}{c}{ Group A } & \multicolumn{4}{c}{ Group B } & \multicolumn{4}{c}{ Group C } \\
\hline Pn & 2.93 & \pm & 0.66 & $\mathrm{a}$ & 1.47 & \pm & 1.15 & $\mathrm{~b}$ & 3.68 & \pm & 1.62 & $\mathrm{a}$ \\
$\mathrm{Gs}$ & 35.80 & \pm & 13.40 & $\mathrm{a}$ & 28.26 & \pm & 16.16 & $\mathrm{a}$ & 67.25 & \pm & 36.23 & $\mathrm{~b}$ \\
$\mathrm{E}$ & 0.77 & \pm & 0.26 & $\mathrm{a}$ & 0.66 & \pm & 0.36 & $\mathrm{a}$ & 1.38 & \pm & 0.67 & $\mathrm{~b}$ \\
$\Psi_{\mathrm{S}}$ & -0.76 & \pm & 0.13 & $\mathrm{a}$ & -0.59 & \pm & 0.14 & $\mathrm{~b}$ & -0.66 & \pm & 0.14 & $\mathrm{ab}$ \\
\hline
\end{tabular}




\subsection{The Transcriptional Response of Grapevine Rootstocks to Drought}

Based on the physiological behavior presented in Figure 2, the gene expression values (VvNCED1, $V v N C E D 2, V v Z E P$ in roots and $V v P P 2 C 4, V v S n R K 2.6, V v A B F 2$ in leaves) were compared among the three groups (A, B and C) by discriminant analysis (Figure 4). Average values and standard error of gene expression for six genes analyzed are reported in Table S2. At 50\% SWC, the three groups showed a different transcriptional behavior: Group A and C rootstocks were discriminated along the first function $(p=0.000)$, while Group A and B rootstocks were discriminated along both the first $(p=0.034)$ and the second $(p=0.000)$ functions (Figure 4a). Functions 1 and 2 accounted for $81.0 \%$ and $19.0 \%$ of total variability, respectively. The most discriminating variables among the groups were the $V v A B F 2$ gene for function 1 and $V v N C E D 1$ and $V v N C E D 2$ genes for function 2. Function 1 was significantly correlated to VvABF2 (0.350) and VvNCED2 (-0.105) gene expression values and function 2 to VvZEP (-0.346), VvNCED1 (-0.644), VvSnRK2.6 (0.443) and VvPP2C4 (0.314) gene expression values. At $20 \%$ SWC, Group A and C rootstocks showed a similar behavior for the first function (0.881), different from the one shown by Group B rootstocks. Group B rootstocks were discriminated along the first function from Group A $(p=0.000)$ and C $(p=0.000)$ rootstocks (Figure $4 \mathrm{~b})$. The second function discriminated Groups A and C (0.021). Functions 1 and 2 accounted for $88.6 \%$ and $11.4 \%$ of total variability, respectively. The most discriminating variables among groups were VvNCED1 and $V v N C E D 2$ genes for function 1 and $V v S n R K 2.6$ and $V v Z E P$ genes for function 2. Function 1 reported significant and positive correlations to $V v P P 2 C 4$ (0.394) and $V v A B F(0.234)$ gene expression values, whereas function 2 reported significant and positive correlations to VvZEP (0.801), VvNCED1 (0.872), VvNCED2 (0.499) and VvSnRK2.6 (0.156) gene expression values.
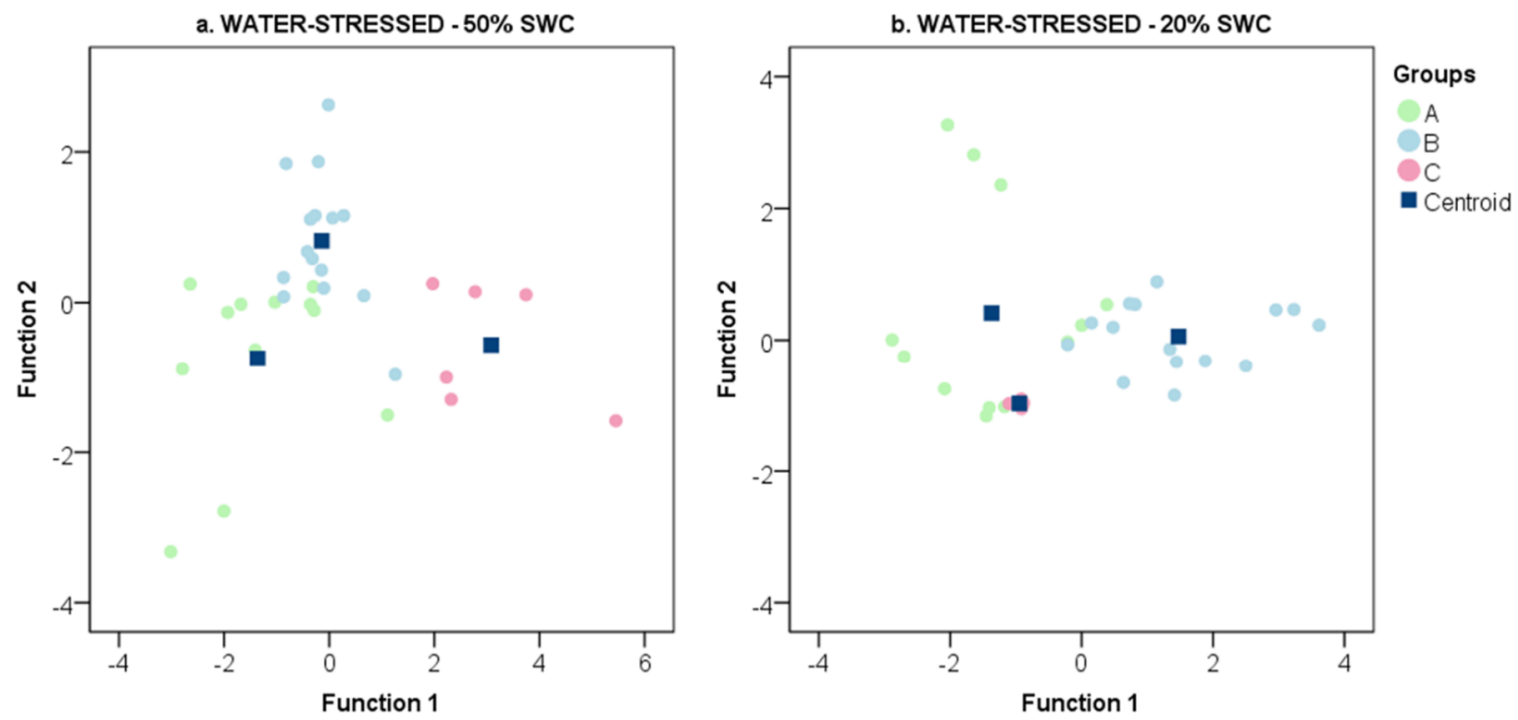

Figure 4. Discriminant analysis of transcript (VvZEP, VvNCED1, VvNCED2, VvPP2C4, VvSnRK2.6 and $V v A B F 2$ genes) abundance data detected for 12 own-rooted grapevine rootstocks grown under limited water conditions. (a) Data collected at 50\% soil water content (SWC). (b) Data collected at $20 \%$ SWC. The genotypes are classified into three groups (A, B and C), as defined in Figure 2, according to the intrinsic water use efficiency. Group A: 1103P, 110R, M1, M3 and M4 rootstocks; Group B: 161-49C, 420A, K5BB, Schwarzmann and SO4 rootstocks; Group C: 140Ru and 41B rootstocks. Discriminant function coefficients are reported in Table S3.

In Figure 5, the gene expression trend of each gene for each group is shown. The VvZEP gene showed a significant increment of transcripts only for Group C rootstocks (Figure 5a). For the VvNCED1 gene, the gene expression levels increased significantly at 50\% SWC and reached the highest value at $20 \%$ SWC for Group A rootstocks (Figure 5b). For VvPP2C4, VvSnK2.6 and VvABF2 genes, Group B rootstocks showed a significant increment of transcripts at 20\% SWC (Figure 5d-f). 

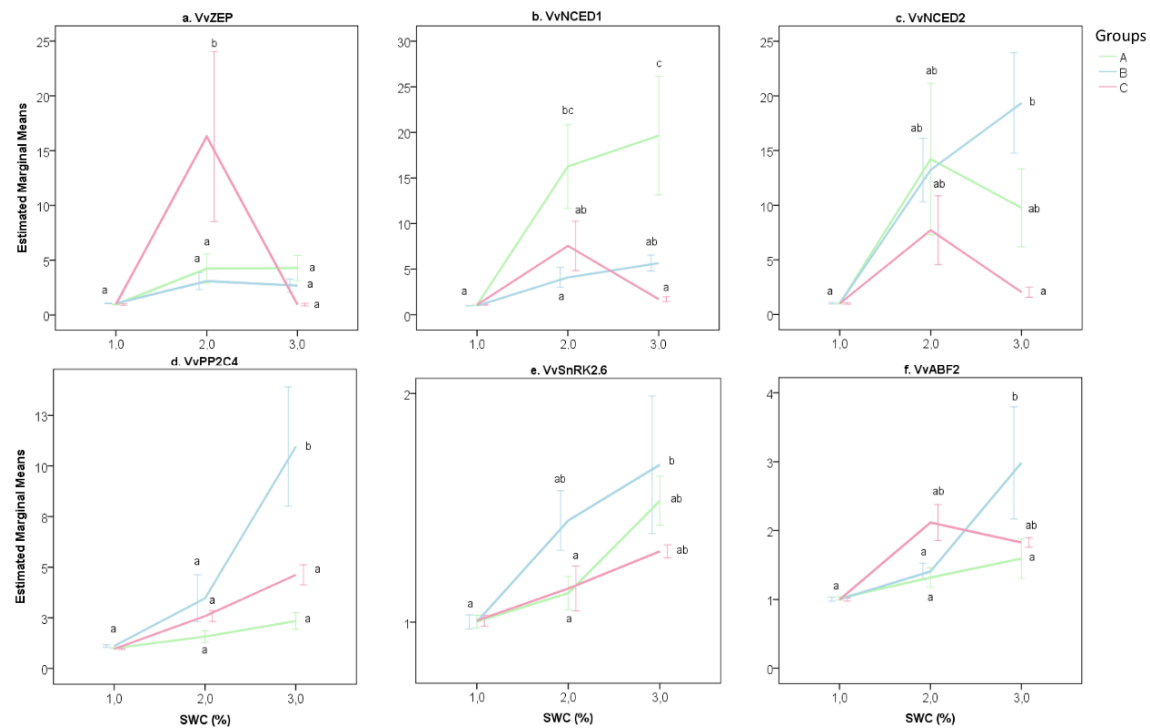

Figure 5. Graphical representation of gene expression data of six genes related to the ABA metabolism in roots (a-c: $V v Z E P, V v N C E D 1$ and $V v N C E D 2)$ and leaves (d-f: $V v P P 2 C 4, V v S n R K 2.6$ and $V v A B F 2)$ of 12 own-rooted grapevine rootstocks grown under limited water conditions (from 80 to $20 \%$ of soil water content, SWC). The genotypes are classified into three groups (A, B and C), as defined in Figure 2, according to the intrinsic water use efficiency. Average values and standard error are shown. Statistical differences are defined according to Tukey's post hoc test at a $p$-value of 0.05. Group A: 1103P, 110R, M1, M3 and M4; Group B: 161-49C, 420A, K5BB, Schwarzmann and SO4; Group C: 140Ru and 41B.

In Figure 6, gas exchange (Pn, Gs, E) detected at 20\% SWC showed a significant negative correlation to the expression of the gene VvNCED1 obtained at 20\% and 50\% SWC. Transpiration and stomatal conductance also showed a negative correlation to VvZEP at 50\% SWC. Vpd at 20\% SWC correlated to $V v N C E D 1$ and VvZEP expressed at 50\% SWC and to VvNCED1 expressed at 20\% SWC. Is detected at $20 \%$ SWC showed a positive correlation to VvZEP at $80 \%$ SWC, but a negative correlation to VvPP2C4 and $V v S n R K 2.6$ at both $80 \%$ and $50 \%$ SWC.

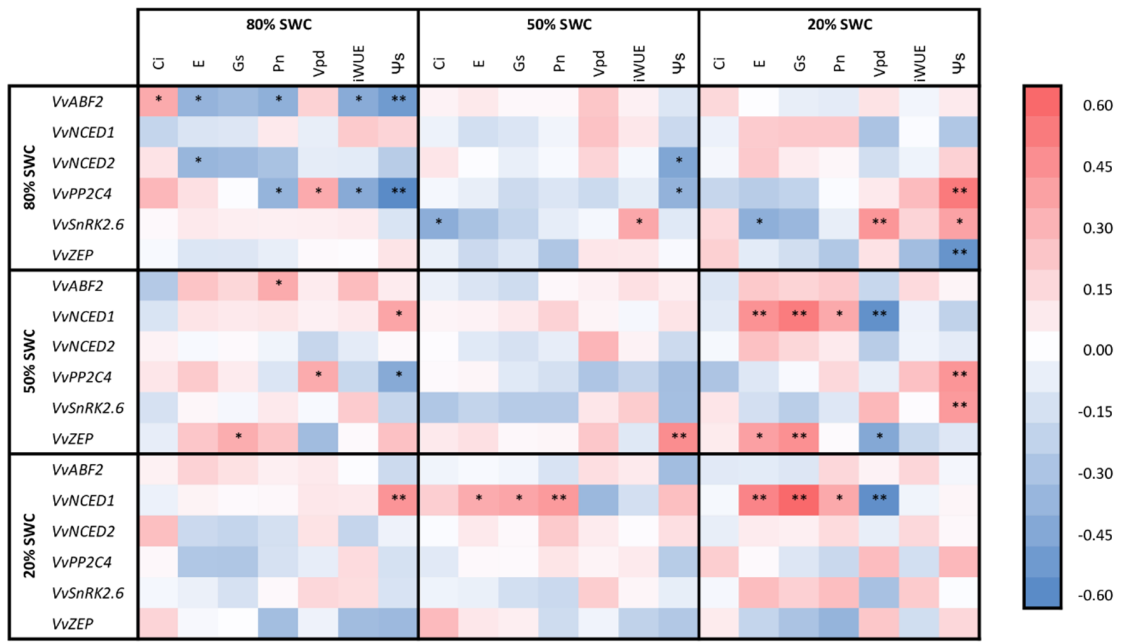

Figure 6. Heatmap of correlation matrix (Pearson index) among physiological (E, Gs, Pn and $\Psi_{\mathrm{S}}$ ) and transcriptional (VvZEP, VvNCED1, VvNCED2, VvPP2C4, VvSnRK2.6 and VvABF2 genes) data detected for 12 own-rooted grapevine rootstocks grown under limited water conditions (from 80 to $20 \%$ soil water content). E: Transpiration; Gs: Stomatal conductance; Pn: Photosynthetic activity; $\Psi_{S}$ : Stem water potential. Statistically significant differences are reported at $0.05\left(^{*}\right)$ and $0.01\left(^{* *}\right)$ levels. 


\section{Discussion}

\subsection{Water-Limiting Conditions for Grapevine Rootstocks}

Grapevines can easily face conditions of mild water stress without their physiological activity being affected, allowing these plants to grow in many marginal areas, usually characterized by limited soil water availability. Roots are the major interface between plants and soil and the first organ to perceive water availability. They are involved in activating key steps for triggering a drought reaction to water stress: signal perception, signal transduction to shoots and leaves and water stress-inducible gene expression (Lovisolo et al., 2016). Therefore, rootstocks play an essential role in the water stress response in grapevines.

In this study, the short-term response to drought of three new-generation (M1, M3 and M4) and nine commercial rootstocks was evaluated. At the physiological level, soil water capacity at $50 \%$ was not a limiting condition for M-rootstocks and the nine commercial rootstocks analyzed, with no statistically significant changes occurring in terms of Pn, Gs, E or $\Psi_{\mathrm{S}}$ in comparison with the well-watered condition ( $80 \%$ SWC). Photosynthetic activity reached by all plants under well-watered conditions was lower than regular field activity due to the adaptation of leaves to moderate light [ PPFD (Photosynthetically active Photon Flux Density) of $600 \mu \mathrm{mol}$ of photons $\left./\left(\mathrm{m}^{2} \times \mathrm{s}\right)\right]$, with values between high and low light conditions obtained by Schubert et al. [48] under field conditions.

\subsection{The Effect of Water Stress on Grapevine Rootstock Genotypes}

Under water deficit conditions $(20 \%$ SWC), the $V$. berlandieri $\times$ V. rupestris hybrids $(140 \mathrm{Ru}, 1103 \mathrm{P}$ and 110R) and the M-rootstocks and 41B rootstocks maintained high photosynthetic activity in comparison with the $V$. riparia $\times V$. berlandieri hybrids and Schwarzmann rootstocks (Figure 1a). Besides photosynthesis, M-rootstocks and $V$. berlandieri $\times V$. rupestris hybrids were more efficient in the use of water under limited conditions, showing higher iWUE values than $V$. riparia $\times V$. berlandieri hybrids and 41B rootstocks (Figure 1b). On reducing the water availability, M3 and M4 rootstocks and most of the commercial rootstocks closed stomata, showing significant differences in Gs values compared to the well-watered condition. M4 and other rootstocks (110R, 161-49C, and SO4) significantly reduced both Gs and Pn values in response to water-stressed conditions (Figure 1). These genotypes are considered "plastic", due to their ability to modify their performances under different environmental conditions [5,49,50]. However, M1 and 140Ru showed an "elastic" behavior, as they maintained unchanged Pn and iWUE levels under both well-watered and water-stressed conditions.

The genetic background of M-rootstocks and nine commercial grapevine rootstocks became discernible in their performances under water-deficit conditions (Figures 1 and 2). In agreement with the literature [23,51,52], the V. riparia $\times$ V. berlandieri hybrids (161-49C, 420A, K5BB and SO4 rootstocks) showed lower tolerance to water stress than $V$. berlandieri $\times V$. rupestris hybrids $(1103 \mathrm{P}, 110 \mathrm{R}$ and $140 \mathrm{Ru}$ rootstocks), with lower Pn values. In Padgett-Johnson et al. [53], V. rupestris showed higher drought tolerance than $V$. riparia and $V$. berlandieri. Schwarzmann (V.riparia $\times V$. rupestris) showed a performance similar to $V$. riparia $\times V$. berlandieri hybrids, whereas $41 \mathrm{~B}$ rootstock $(V$. berlandieri $\times V$. vinifera), typically classified as a tolerant genotype, showed a behavior similar to $V$. berlandieri $\times V$. rupestris hybrids.

In our study, the performances of M-rootstocks (M1, M3 and M4), characterized by different genetic backgrounds, were similar to those shown by the $V$. berlandieri $\times V$. rupestris hybrids $1103 \mathrm{P}$ and 110R. M4 (unknown $\times 1103 \mathrm{P}$ ) and 1103P rootstocks, both considered highly tolerant to water stress $[23,54,55]$, showed similar performances (Figure 2).

A recent study compared M4 to 1103P in grafting combination with Grechetto Gentile. The two combinations maintained similar water potential under water stress, though M4 showed higher photosynthesis and water use efficiency [56]. Galbignani et al. [57] found higher Pn values and higher instantaneous WUE values in Sangiovese grafted on M4 than grafted on SO4 under moderately water-stressed conditions. 
Vitis species possess the ability to show different strategic behaviors in response to drought [53]. In this study, three different strategies based on gas exchange and iWUE were identified in response to severe water-deficit conditions: (i) M-rootstocks (M1, M3 and M4) and 1103P and 110R rootstocks showed high Pn at limiting Gs values (Group A); (ii) Schwarzmann rootstock and V. riparia $\times$ V. berlandieri hybrids showed low Pn values at low Gs values (Group B); (iii) 140Ru and 41B rootstocks showed high Pn values without a reduction of Gs values (Group C) (Figure 2).

The three groups reported differences in stem water potential under low SWC (Figure 3a), as well as in the expression of genes related to ABA biosynthesis and signaling (Figure 4).

\subsection{Delineation of Group Strategies to Face Drought}

Based on physiological performance under water-limiting conditions, the rootstocks were classified into three groups (A, B and C) (Figure 2). The same three clusters were clearly discriminated according to the expression of six genes related to the ABA pathway in both mild (50\% SWC) and limiting (20\% SWC) water-stressed conditions (Figure 4). ABA mediates many physiological responses of plants to drought, including avoidance as well as tolerance responses. It is synthesized in both roots and leaves [24]. In both organs, its levels increase upon exposure to drought and they are accompanied by major changes in gene expression and physiological responses, such as stomatal closure [17]. Differences among groups in physiological activity were only detected under water-limiting conditions ( $20 \%$ SWC), nevertheless, the three groups were clearly discriminated at mildly water stress ( $50 \%$ SWC) according to their gene expression (Figure 4). At 20\% SWC, the discriminant function 1 correlated with $V v P P 2 C 4$ and $V v A B F 2$ gene expression in leaves, involved in the ABA signal transduction $[40,58,59]$. Discriminant function 2 was mainly correlated with $V v Z E P, V v N C E D 1$ and $V v N C E D 2$ gene expression in roots, involved in ABA biosynthesis [34,59].

Vines can use several strategies for drought adaptation, including avoidance, tolerance and resistance [60,61]. The expression of genes related to the ABA biosynthetic pathway helped to investigate the strategies adopted by groups to deal with the water deficiency. Group A rootstocks (M1, M3, M4, 1103P and 110R) experienced stress at 20\% SWC (Figure 2), increasing the transcription of genes related to ABA biosynthesis, especially VvNCED1 and VvNCED2 (Figure 5b-c). However, they showed a low expression of genes linked to ABA signal transduction, showing negative values of discriminant function 1 (Figure $4 \mathrm{~b}$ ). The evidence that genes related to ABA signal transduction $(V v P P 2 C 4, V v S n R K 2.6, V v A B F 2)$ showed low levels of gene expression at low Gs levels allows us to suppose that the stomatal closure in response to ABA increase might be associated with a different mechanism. An alternative way to achieve a fast increase in ABA content is via hydrolysis of the ABA-glucosyl ester (ABA-GE), an inactive glucose-conjugated form of ABA [59]. Nevertheless, Group A rootstocks reduced the stomatal conductance, despite which they retained high Pn activity, proving high water use efficiency (Figure $1 b$, Figure 2). Photosynthetic activity and stomatal closure involved reductions of both sub-stomatal $\mathrm{CO}_{2}$ concentration $(\mathrm{Ci})$ and vapor pressure deficit $(\mathrm{Vpd})$. This performance could be ensured by an efficient ROS detoxification system, for which gene expression was noticed for the M4 rootstock under water-stressed conditions by Corso et al. [48]. (Figure 3) The rootstocks clustered in Group A, including the M-rootstocks (M1, M3 and M4), adopted a tolerant strategy [61], preserving their physiological activity under water stress.

Rootstocks belonging to Group B (161-49C, 420A, K5BB, Schwarzmann and SO4) also reduced the physiological activity at 20\% SWC (Figure 1b). Among genes related to ABA biosynthesis, they mainly increased transcripts of $V v A P F 2, V v N C E D 2$ and VvPP2C4 genes (Figure 5c-d). According to the literature, the enhanced activity of $V v P P 2 C$ genes during drought stress suggests that its primary role is in regulating ABA response [40,41,58]. As reported by Boneh et al. [40] and Rattanakon et al. [59], transcripts of $P P 2 C$ genes increase to slow down the activation of the ABA signaling pathway that occurs from a rapid rise in the hormone itself. For Group B rootstocks, stomatal conductance decreased, as well as photosynthetic activity, showing low efficiency in water use (Figure 1b, Figure 2). For this group, low stomatal conductance seemed to buffer the drop in $\Psi_{S}$ values at decreasing SWC levels 
(Figure 3a-b). (Figure 6) The strategy adopted by Group B genotypes under water-stressed conditions can be defined as avoidance [61], preserving $\Psi_{S}$ by reducing the physiological activity through stomatal closure. The high water potential indicates that this could be adopted in long-term drought conditions.

Unlike other rootstocks, Group C rootstocks (140Ru and 41B) maintained the stomatal conductance under 20\% SWC, allowing leaves to continue high photosynthetic activity (Figure 2), regardless of $\Psi_{S}$ (Figure 3b). The physiological activity performed at $20 \%$ SWC could be related to the adaptation of genotype architecture to drought conditions, such as the vessel size $[5,62,63]$. (Figure 6) However, the expression of genes linked to ABA biosynthesis, especially VvZEP, rose at 50\% SWC before decreasing at lower water availability (Figure 5a). Group $C$ rootstocks showed a resistant strategy to water stress under water-limited conditions.

\section{Material and Methods}

\subsection{Plant Material and Growth Conditions}

The experiment was conducted in June 2017, under environmentally controlled conditions in a greenhouse at DiSAA (University of Milan). The greenhouse was equipped with supplementary light and a cooling system, with a $16 \mathrm{hr}$ light [ PPFD of $600 \mu \mathrm{mol}$ of photons $\left./\left(\mathrm{m}^{2} \times \mathrm{s}\right)\right]$ and $8 \mathrm{hr}$ dark photoperiod and a range of temperatures from 23 to $28^{\circ} \mathrm{C}$. A total of twelve grapevine rootstocks were analyzed: 1103P, 110R, 114Ru, 161-49C, 41B, 420A, K5BB, Schwarzmann, SO4, used worldwide, and the newly released M1, M3, M4. Nine biological repetitions per genotype were monitored. Two-year-old cuttings were used. The vines were grown in $4 \mathrm{~L}$ plastic pots, trained on $1 \mathrm{~m}$ stakes and placed in a randomized complete block design. The growth substrate was composed of $70 \%$ sand and $30 \%$ peat, supplemented with a layer of expanded clay aggregate on the bottom of the pot to avoid water flooding. During the phenological phase of budding, the plants were maintained in well-watered conditions in order to develop a well-expanded canopy.

\subsection{Irrigation Management and Treatments}

Three treatments were performed: $80 \%, 50 \%$ and $20 \%$ soil water content (SWC). Per treatment, three plants were collected, which were considered as biological replications. The SWC was calculated using the gravimetric method, according to the formula suggested by Gardner et al. [64]:

$$
S W C=\frac{(\text { fresh weight }- \text { dry weight })}{\text { dry weight }} 100
$$

where fresh weight refers to the soil weight at field capacity and dry weight to the soil dried in an oven at $105^{\circ} \mathrm{C}$ for $48 \mathrm{~h}$.

Each pot containing one plant was weighed daily for a period of 10 days. When SWC reached the values of $80 \%, 50 \%$ and $20 \%$, plants were selected for measurement of physiological parameters and gene expression analysis.

\subsection{Plant Phenotyping}

At each time point $(80 \%, 50 \%$ and $20 \%$ SWC), gas exchange parameters and stem water potential $\left(\Psi_{S}\right)$ were evaluated in three different plants (replications) per rootstock. Both measurements were carried out between 11:00 a.m. and 2:00 p.m. solar time.

Two fully expanded leaves (8th and 9th leaf) per plant were selected to measure gas exchange indicators: photosynthetic activity $\left(\mathrm{Pn} ; \mu \mathrm{molCO} \mathrm{m}^{-2} \mathrm{~s}^{-1}\right)$, stomatal conductance (Gs; $\mathrm{mmol} \mathrm{H}_{2} \mathrm{O} \mathrm{m}^{-2} \mathrm{~s}^{-1}$ ) and transpiration (E; mmol $\mathrm{H}_{2} \mathrm{O} \mathrm{m}^{-2} \mathrm{~s}^{-1}$ ). Gas exchange was measured with a leaf portable photosynthesis system (CIRAS-2, PP Systems, Amesbury, MA, USA) equipped with PLC6 (U) cuvette $18 \mathrm{~mm}$ circular $\left(2.5 \mathrm{~cm}^{2}\right.$ head plate), under constant saturating PPFD of $1500 \mu \mathrm{mol}$ photons $\mathrm{m}^{-2} \mathrm{~s}^{-1}$, $\mathrm{CO}_{2}$ concentration of $300 \mu \mathrm{mol} \mathrm{mol}{ }^{-1}$, block temperature of $25^{\circ} \mathrm{C}$ and relative humidity between $60 \%$ 
and $70 \%$ allowing $~ 1.5 \mathrm{kPa}$ of $\mathrm{Vpd}$ inside the leaf chamber. Intrinsic water use efficiency (iWUE) was calculated as the $\mathrm{Pn} / \mathrm{Gs}$ ratio and expressed as $\mu \mathrm{mol} \mathrm{CO} 2 \mathrm{~mol}^{-1} \mathrm{H}_{2} \mathrm{O}$.

As suggested by Scholander et al. [65], $\Psi_{S}(\mathrm{MPa})$ was calculated using the Scholander pressure chamber (Soil Moisture Equipment Corporation, Santa Barbara, CA, USA). The same leaves used to evaluate gas exchange were placed in a plastic bag wrapped in aluminum foil for $1 \mathrm{hr}$. Subsequently, they were excised with a razor blade and put in the Scholander chamber for the analysis. The $\Psi_{S}$ value was recorded within $30 \mathrm{~s}$ from the cutting of the leaf by slowly pressurizing the chamber until sap came out from the cut end of the petiole.

\subsection{Gene Expression Analysis}

After the in vivo measurements of physiological parameters at $80 \%, 50 \%$ and $20 \%$ SWC, the whole root system and fully expanded leaves (i.e., from the fifth to the eighth node of the primary shoot) of the same plants per rootstock were immediately sampled, frozen in liquid nitrogen and stored at $-80^{\circ} \mathrm{C}$ until RNA extraction. The total RNA was extracted from $100 \mathrm{mg}$ of liquid nitrogen-ground tissue with a Spectrum $^{\mathrm{TM}}$ Plant Total RNA (Sigma-Aldrich, Germany) commercial kit, according to the manufacturer's instructions. To evaluate RNA quality, 260/230 and 260/280 ratios were checked via a NanoDrop Spectrophotometer (Thermo Scientific, MA, USA). For those samples showing a 260/230 absorbance ratio lower than 1.8, a lithium chloride treatment was carried out (as reported in De Lorenzis et al. [66]). RNA integrity was checked by electrophoresis on $1.5 \%$ agarose gel. RNA quantification was performed using a Qubit ${ }^{\circledR}$ RNA HS Assay Kit by Qubit ${ }^{\circledR} 3.0$ Fluorometer (Life Technologies, Carlsbad, CA, USA).

Total RNA (200 ng) was used to synthetize cDNA using 200 U of SuperScript ${ }^{\circledR}$ III Reverse Transcriptase (Thermo Fisher) and $50 \mu \mathrm{M}$ oligo $(\mathrm{dT})_{20}$ primers in accordance with the manufacturer's instructions. Six genes (Table 3) involved in the response to drought were evaluated via real-time RT-PCR. VvZEP, VvNCED1 and VVNCED2 genes were evaluated in roots and VvPP2C4, VVSnRK2.6 and $V v A B F 2$ genes were evaluated in leaves, based on previous evidence reporting that genes related to ABA biosynthesis are mainly associated with ABA increases in water-stressed roots [33,34], while genes related to the ABA signal transduction better discriminate the genotypes at leaf level [34]. Ubiquitin (UBI; [67]) and actin (ACT; [68]) were used as reference genes. RT-PCR was carried out in a 7300 Real-Time PCR System (Applied Biosystems, Foster City, CA, USA). For each reaction (20 $\mu \mathrm{L}), 200 \mathrm{nM}$ of each primer, $2 \mu \mathrm{L}$ of cDNA (1:100 dilution of the synthesis reaction), 1X SYBR Green Real-Time PCR Master Mix (Thermo Fisher) and water up to $20 \mu \mathrm{L}$ were added. Thermal cycling involved pre-incubation at $95^{\circ} \mathrm{C}$ for $3 \mathrm{~min}$, followed by 40 cycles of $94^{\circ} \mathrm{C}$ for $15 \mathrm{~s}, 58^{\circ} \mathrm{C}$ for $20 \mathrm{~s}$ and $72{ }^{\circ} \mathrm{C}$ for $30 \mathrm{~s}$. For detecting non-specific amplifications in cDNA samples, a melting cycle with temperatures ranging from 65 to $95{ }^{\circ} \mathrm{C}$ was performed. Each real-time RT-PCR reaction was completed in triplicate. After testing the suitability of ubiquitin and actin as reference genes, ubiquitin was selected to normalize the cycle threshold $(\mathrm{Ct})$ values of all analyzed samples, due to a PCR efficiency value more similar to the ones observed for target genes (ranging from 93 to 97\%). The expression of each gene in different genotypes and water conditions was calculated by comparing their $2^{-\Delta \Delta \mathrm{Ct}}$ values [69]. 
Table 3. List of genes evaluated via real-time RT-PCR in roots and leaves of 12 own-rooted grapevine rootstocks grown under water deprivation.

\begin{tabular}{|c|c|c|c|}
\hline Genes & Primer Sequence $\left(5^{\prime} \rightarrow 3^{\prime}\right)$ & Reference & Tissue \\
\hline$V v Z E P$ & $\begin{array}{c}\text { F: GGTAAGAAGGAAAGGTTGC } \\
\text { R: CAATAGGAGTCCCTGATTTGATGC }\end{array}$ & Hayes et al. [70] & \multirow{3}{*}{ roots } \\
\hline VvNCED1 & $\begin{array}{l}\text { F: TGCAGAGGACGAGAGTGTAA } \\
\text { R: AGCTACACCAAAAGCTACGA }\end{array}$ & Hayes et al. [70] & \\
\hline VvNCED2 & $\begin{array}{l}\text { F: ATGCTCAAACCGCCTCTGAT } \\
\text { R: TCCCAAGCATTCCAGAGGTG }\end{array}$ & Lund et al. [71] & \\
\hline$V v P P 2 C 4$ & $\begin{array}{l}\text { F: TGGGCTTTGGGATGTTATGT } \\
\text { R: TGTGCAGGAGTCTCATCAGC }\end{array}$ & Boneh et al. [40] & \multirow{3}{*}{ leaves } \\
\hline $\operatorname{VvSnRK2.6}$ & $\begin{array}{l}\text { F: CACCAACCCACCTTGCTATT } \\
\text { R: AAACGTGCCTCATCCTCACT }\end{array}$ & Boneh et al. [40] & \\
\hline$V v A B F 2$ & $\begin{array}{c}\text { F: GGCACCCAGGCTAGTTAA } \\
\text { R: GCAGAGTACACGCTAGATTG }\end{array}$ & Rossdeutsch et al. [34] & \\
\hline
\end{tabular}

\subsection{Statistical Analysis}

Data were analyzed using Microsoft Office Excel and SPSS statistical software (IBM SPSS Statistics 24). A univariate ANOVA model was performed on phenotypical parameters (Pn, Gs, E and $\Psi_{S}$ ) at $p \leq 0.05$ after checking for the assumption of normality and homogeneity of variance. Post hoc comparisons were performed on phenotypical parameters (Pn, Gs, E and $\Psi_{\mathrm{S}}$ ) with Tukey's post hoc test at $p \leq 0.05$. Gene expression data were used to perform a discriminant analysis, using the values as independent variables and with equal prior probabilities. Groups were identified by a bi-plot of Pn and Gs using the available water-stressed threshold for $\mathrm{Gs}\left(50 \mathrm{mmol} \mathrm{H}_{2} \mathrm{O} \mathrm{m}^{-2} \mathrm{~s}^{-1}\right.$, based on Cifre et al. [49]) and the mean value for Pn. Differences among groups in terms of discriminant function scores and gene expression were detected by a univariate ANOVA model and Tukey's post-hoc test at $p \leq 0.05$. Correlation among phenotypical parameters and gene expression was determined by Pearson's index at $p=0.05\left(^{*}\right)$ and $p=0.01\left(^{* *}\right)$ and viewed as a heatmap.

\section{Conclusions}

In this study, the new M-rootstocks showed a reaction to water-stressed conditions similar to that of the 1103P and 110R rootstocks, two commercial genotypes typically classified as being highly tolerant. They adopted a tolerant strategy, increasing the transcripts of genes related to ABA biosynthesis, especially $V v N C E D 1$ and $V v N C E D 2$, maintaining high water use efficiency under water-stressed conditions and preserving physiological activity even with low levels of stomatal conductance. Further studies will be necessary to confirm the performance of M-rootstocks under water stress in field conditions, evaluating rootstock/scion interactions. Nevertheless, a few new grapevine rootstock genotypes are not enough to face the challenges that modern viticulture will have to cope with in the future, therefore, new breeding programs have to be planned.

Supplementary Materials: The following are available online at http://www.mdpi.com/2223-7747/9/10/1385/s1, Figure S1. Effect of water availability decreasing (50 and 20\% SWC; soil water content) in 12 own-rooted grapevine rootstocks on (a) net photosynthesis (Pn), (b) stomatal conductance (Gs), (c) transpiration (E) and (d) stem water potential (YS) in respect to the well-watered condition ( $80 \%$ SWC). $\Psi$ S values were normalized on well-watered condition values. Statistical differences among different water conditions for each parameter are defined according to Tukey post-hoc test at p-value 0.05 . Well-watered plants were maintained at $80 \%$ SWC and compared to water-stressed plants at 50 and $20 \%$ SWC. At 50\% SWC, Pn activity amounted to $3.90 \mu \mathrm{mol} \mathrm{CO} 2 \mathrm{~m}-2 \mathrm{~s}-1$, Gs to $124 \mathrm{mmol} \mathrm{H} 2 \mathrm{O} \mathrm{m}-2 \mathrm{~s}-1, \mathrm{E}$ to $1.61 \mathrm{mmol} \mathrm{H} 2 \mathrm{O} \mathrm{m}-2 \mathrm{~s}-1$ and $\Psi \mathrm{S}$ to $-0.42 \mathrm{MPa}$ (about $113 \%$ in comparison to well-watered condition) (Figure 1). Average values of all physiological parameters were not significantly different in comparison with those of the well-watered condition. At $20 \%$ SWC, water availability significantly affected all the investigated physiological parameters (Figure 1). Plants reduced all the physiological parameters, showing significant differences in comparison to the well-watered plants: Pn was $2.47 \mu$ mol CO2 m-2 s- 1 (about $37 \%$ less than $80 \%$ SWC); Gs was $38 \mathrm{mmol} \mathrm{H} 2 \mathrm{O} \mathrm{m}-2 \mathrm{~s}-1$ (about $69 \%$ less than well-watered condition); E was $0.83 \mathrm{mmol} \mathrm{H} 2 \mathrm{O}$ 
m-2 s-1 (about 48\% less in comparison to well-watered condition); $\Psi$ S dropped to -0.67 MPa, Table S1: Average values and standard error of physiological parameters measured for 12 own-rooted grapevine rootstocks under both well-watered ( $80 \%$ soil water content, SWC) and water-stressed ( $20 \%$ SWC) conditions, Table S2: Average values and standard error of gene expression for six genes detected for 12 own-rooted grapevine rootstocks under both well-watered ( $80 \%$ soil water content, SWC) and water-stressed ( $20 \%$ SWC) conditions, Table S3: Standardized canonical discriminant function coefficients for function 1 and function 2 at 50 and $20 \%$ soil water content (SWC) for gene expression values of six genes detected in 12 own-rooted grapevine rootstocks.

Author Contributions: Conceptualization, L.B. and G.D.L.; methodology, D.B., L.C. and D.G.; data curation, D.B. and G.D.L.; writing-original draft preparation, D.B. and G.D.L.; writing-review and editing, L.B. and G.D.L. All authors have read and agreed to the published version of the manuscript.

Funding: This research received no external funding.

Acknowledgments: The authors thanks Vivai Cooperativi Rauscedo (Rauscedo, Italy) and WineGraft srl (Lodi, Italy) for providing plants.

Conflicts of Interest: The authors declare no conflict of interest.

\section{References}

1. Chaves, M.M.; Maroco, J.P.; Pereira, J.S. Understanding plant responses to drought-From genes to the whole plant. Funct. Plant Biol. 2003, 30, 239. [CrossRef] [PubMed]

2. Pellegrino, A.; Lebon, E.; Simonneau, T.; Wery, J. Towards a simple indicator of water stress in grapevine (Vitis vinifera L.) based on the differential sensitivities. Aust. J. Grape Wine Res. 2005, 11, 306-315. [CrossRef]

3. Jackson, D.I.; Lombard, P.B. Environmental and Management Practices Affecting Grape Composition and Wine Quality-A Review. Am. J. Enol. Vitic. 1993, 44, 409-430.

4. Gale, G. Saving the vine from Phylloxera: A never-ending battle. In Wine: A Scientifc Exploration; Sandler, M., Pindler, R., Eds.; Taylor and Francis: London, UK, 2002; pp. 70-91, ISBN 9780203361382.

5. Bianchi, D.; Grossi, D.; Tincani, D.T.G.; Simone Di Lorenzo, G.; Brancadoro, L.; Rustioni, L. Multi-parameter characterization of water stress tolerance in Vitis hybrids for new rootstock selection. Plant Physiol. Biochem. 2018, 132, 333-340. [CrossRef]

6. Bianchi, D.; Grossi, D.; Simone Di Lorenzo, G.; Zi Ying, Y.; Rustioni, L.; Brancadoro, L. Phenotyping of the "G series" Vitis hybrids: First screening of the mineral composition. Sci. Hortic. 2020, 264. [CrossRef]

7. Cochetel, N.; Escudié, F.; Cookson, S.J.; Dai, Z.; Vivin, P.; Bert, P.; Muñoz, M.S.; Delrot, S.; Klopp, C.; Ollat, N.; et al. Root transcriptomic responses of grafted grapevines to heterogeneous nitrogen availability depend on rootstock genotype. J. Exp. Bot. 2017, 68, 4339-4355. [CrossRef]

8. Vannozzi, A.; Donnini, S.; Vigani, G.; Corso, M.; Valle, G.; Vitulo, N.; Bonghi, C.; Zocchi, G.; Lucchin, M. Transcriptional Characterization of a Widely-Used Grapevine Rootstock Genotype under Different Iron-Limited Conditions. Front. Plant Sci. 2017, 7, 1-17. [CrossRef] [PubMed]

9. Ollat, N.; Peccoux, A.; Papura, D.; Esmenjaud, D.; Marguerit, E.; Tandonnet, J.P.; Bordenave, L.; Cookson, S.J.; Barrieu, F.; Rossdeutsch, L.; et al. Rootstocks as a Component of Adaptation to Environment; Wiley: Hoboken, NJ, USA, 2016; ISBN 9781118735985.

10. IPCC. Global warming of $1.5^{\circ} \mathrm{C}$. In Summary for Policymarkerskers; World Meteorological Organization: Geneva, Switzerland, 2018; pp. 1-26, ISBN 9789291691517.

11. Giorgi, F.; Lionello, P. Climate change projections for the Mediterranean region. Glob. Planet. Chang. 2008, 63, 90-104. [CrossRef]

12. IPCC. Climate Change 2013: The Physical Science Basis-Summary for Policymakers; Cambridge University Press: Cambridge, UK, 2013.

13. Schultz, H.R. Climate change and viticulture: A European perspective on climatology, carbon dioxide and UV-B effects. Aust. J. Grape Wine Res. 2000, 6, 2-12. [CrossRef]

14. Taiz, L.; Zeiger, E. Plant physiology. 3rd edn. Ann. Bot. 2003, 91, 750-751. [CrossRef]

15. Shao, H.B.; Chu, L.Y.; Shao, M.A.; Abdul Jaleel, C.; Hong-Mei, M. Higher plant antioxidants and redox signaling under environmental stresses. Comp. Rend. Biol. 2008, 331, 433-441. [CrossRef]

16. Steudle, E. Water uptake by roots: Effects of water deficit. J. Exp. Bot. 2000, 51, 1531-1542. [CrossRef] [PubMed] 
17. Tombesi, S.; Nardini, A.; Frioni, T.; Soccolini, M.; Zadra, C.; Farinelli, D.; Poni, S.; Palliotti, A. Stomatal closure is induced by hydraulic signals and maintained by ABA in drought-stressed grapevine. Sci. Rep. 2015, 5, 1-12. [CrossRef]

18. Schachtman, D.P.; Goodger, J.Q.D. Chemical root to shoot signaling under drought. Trends Plant Sci. 2008, 13, 281-287. [CrossRef] [PubMed]

19. Jones, H.; Sutherland, R. Stomatal control of xylem embolism. Plant Cell Environ. 1991, 14, 607-612. [CrossRef]

20. Hochberg, U.; Herrera, J.C.; Cochard, H.; Badel, E. Short-time xylem relaxation results in reliable quantification of embolism in grapevine petioles and sheds new light on their hydraulic strategy. Tree Physiol. 2016, 36, 748-755. [CrossRef] [PubMed]

21. Medrano, H.; Tomás, M.; Martorell, S.; Flexas, J.; Hernández, E.; Rosselló, J.; Pou, A.; Escalona, J.M.; Bota, J. From leaf to whole-plant water use efficiency (WUE) in complex canopies: Limitations of leaf WUE as a selection target. Crop J. 2015, 3, 220-228. [CrossRef]

22. Farquhar, G.D.; Sharkey, T.D. Stomatal conductance and photosynthesis. Ann. Rev. Plant Biol. 1982, 61, 561-591. [CrossRef]

23. Lovisolo, C.; Lavoie-lamoureux, A.; Tramontini, S.; Ferrandino, A. Grapevine adaptations to water stress: New perspectives about soil/plant interactions. Theor. Exp. Plant Physiol. 2016, 28, 53-66. [CrossRef]

24. De Smet, I.; Zhang, H. Abscisic acid in root growth and development. In Plant Roots: The Hidden Half; Eshel, A., Beeckman, T., Eds.; CRC Press: Baton Rouge, FL, USA, 2013; pp. 16.1-16.13.

25. Audran, C.; Borel, C.; Frey, A.; Sotta, B.; Meyer, C.; Simonneau, T.; Marion-Poll, A. Expression studies of the zeaxanthin epoxidase gene in Nicotiana plumbaginifolia. Plant Physiol. 1998, 118, 1021-1028. [CrossRef]

26. Ikegami, K.; Okamoto, M.; Seo, M.; Koshiba, T. Activation of abscisic acid biosynthesis in the leaves of Arabidopsis thaliana in response to water deficit. J. Plant Res. 2009, 122, 235-243. [CrossRef] [PubMed]

27. Manzi, M.; Lado, J.; Rodrigo, M.J.; Zacariás, L.; Arbona, V.; Gómez-Cadenas, A. Root ABA Accumulation in Long-Term Water-Stressed Plants is Sustained by Hormone Transport from Aerial Organs. Plant Cell Physiol. 2015, 56, 2457-2466. [CrossRef] [PubMed]

28. Manzi, M.; Lado, J.; Rodrigo, M.J.; Arbona, V.; Gómez-Cadenas, A. ABA accumulation in water-stressed Citrus roots does not rely on carotenoid content in this organ. Plant Sci. 2016, 252, 151-161. [CrossRef] [PubMed]

29. McAdam, S.A.M.; Brodribb, T.J.; Ross, J.J. Shoot-derived abscisic acid promotes root growth. Plant Cell Environ. 2016, 39, 652-659. [CrossRef] [PubMed]

30. Ren, H.; Gao, Z.; Chen, L.; Wei, K.; Liu, J.; Fan, Y.; Davies, W.J.; Jia, W.; Zhang, J. Dynamic analysis of ABA accumulation in relation to the rate of ABA catabolism in maize tissues under water deficit. J. Exp. Bot. 2007, 58, 211-219. [CrossRef] [PubMed]

31. Rock, C.D.; Heath, T.G.; Gage, D.A.; Zeevaart, J.A. Abscisic alcohol is an intermediate in abscisic Acid biosynthesis in a shunt pathway from abscisic aldehyde. Plant Physiol. 1991, 97, 670-676. [CrossRef] [PubMed]

32. Qin, X.; Zeevaart, J.A. The 9-cis-epoxycarotenoid cleavage reaction is the key regulatory step of abscisic acid biosynthesis in water-stressed bean. Proc. Natl. Acad. Sci. USA 1999, 96, 15354-15361. [CrossRef]

33. Speirs, J.; Binney, A.; Collins, M.; Edwards, E.; Loveys, B. Expression of ABA synthesis and metabolism genes under different irrigation strategies and atmospheric VPDs is associated with stomatal conductance in grapevine (Vitis vinifera L. cv Cabernet Sauvignon). J. Exp. Bot. 2013, 64, 1907-1916. [CrossRef]

34. Rossdeutsch, L.; Edwards, E.; Cookson, S.J.; Barrieu, F.; Gambetta, G.A.; Delrot, S.; Ollat, N. ABA-mediated responses to water deficit separate grapevine genotypes by their genetic background. BMC Plant Biol. 2016, 16, 91. [CrossRef]

35. Iuchi, S.; Kobayashi, M.; Taji, T.; Naramoto, M.; Seki, M.; Kato, T. Regulation of drought tolerance by gene manipulation of 9- cis -epoxycarotenoid dioxygenase, a key enzyme in abscisic acid biosynthesis in Arabidopsis. Plant J. 2001, 27, 325-333. [CrossRef]

36. Santiago, J.; Rodrigues, A.; Saez, A.; Rubio, S.; Antoni, R.; Dupeux, F.; Park, S.; Marquez, J.; Cutler, S.; Rodriguez, P. Modulation of drought resistance by the abscisic acid receptor PYL5 through inhibition of clade A PP2Cs. Plant J. 2009, 60, 575-588. [CrossRef] [PubMed]

37. Yoshida, R.; Hobo, T.; Ichimura, K.; Mizoguchi, T.; Takahashi, F.; Aronso, J.; Ecker, J.R.; Shinozaki, K. ABA-Activated SnRK2 Protein Kinase is Required for Dehydration Stress Signaling in Arabidopsis. Plant Cell Physiol. 2002, 43, 1473-1483. [CrossRef] 
38. Raghavendra, A.S.; Gonugunta, V.K.; Christmann, A.; Grill, E. ABA perception and signalling. Trends Plant Sci. 2010, 15, 395-401. [CrossRef]

39. Soar, C.J.; Speirs, J.; Maffei, S.M.; Penrose, A.B.; Mc Carthy, M.G. Grape vine varieties Shiraz and Grenache differ in their stomatal response to VPD: Apparent links with ABA physiology and gene expression in leaf tissue. Aust. J. Grape Wine Res. 2006, 12, 2-12. [CrossRef]

40. Boneh, U.; Biton, I.; Zheng, C.; Schwartz, A.; Ben-Ari, G. Characterization of potential ABA receptors in Vitis vinifera. Plant Cell Rep. 2012, 31, 311-321. [CrossRef]

41. Haider, M.S.; Zhang, C.; Kurjogi, M.M.; Pervaiz, T.; Zheng, T.; Zhang, C.; Lide, C.; Shangguan, L.; Fang, J. Insights into grapevine defense response against drought as revealed by biochemical, physiological and RNA-Seq analysis. Sci. Rep. 2017, 7, 13134. [CrossRef] [PubMed]

42. Vivier, M.A.; Pretorius, I.S. Genetically tailored grapevines for the wine industry. Trends Biotechnol. 2002, 20, 472-478. [CrossRef]

43. Migliaro, D.; De Lorenzis, G.; Di Lorenzo, G.S.; Nardi, B.D.; Gardiman, M.; Failla, O.; Brancadoro, L.; Crespan, M. Grapevine non-vinifera genetic diversity assessed by simple sequence repeat markers as a starting point for new rootstock breeding programs. Am. J. Enol. Vitic. 2019, 70, 390-397. [CrossRef]

44. Bianchi, D.; Brancadoro, L.; De Lorenzis, G. Genetic Diversity and Population Structure in a Vitis spp. Core Collection Investigated by SNP Markers. Diversity 2020, 12, 103. [CrossRef]

45. Keller, M. The Science of Grapevines. Anatomy and Physiology; Elsevier: Amsterdam, The Netherlands, 2015; ISBN 9780124199873.

46. Porro, D.; Pedò, S.; Bertoldi, D.; Bortolotti, L.; Failla, O.; Zamboni, M. Evaluation of New Rootstocks for Grapevine: Nutritional Aspects. Acta Hortic. 2013, 984, 109-115. [CrossRef]

47. Cifre, J.; Bota, J.; Escalona, J.M.; Medrano, H.; Flexas, J. Physiological tools for irrigation scheduling in grapevine (Vitis vinifera L.) An open gate to improve water-use efficiency? Agric. Ecosyst. Environ. 2005, 106, 159-170. [CrossRef]

48. Schubert, A.; Restagno, M.; Lovisolo, C. Photosynthesis of grapevine leaves of different age at high and low light intensity. Strateg. Optim. Wine Grape Qual. 1996. [CrossRef]

49. Dal Santo, S.; Zenoni, S.; Sandri, M.; De Lorenzis, G.; Magris, G.; De Paoli, E.; Di Gaspero, G.; Del Fabbro, C.; Morgante, M.; Brancadoro, L.; et al. Grapevine field experiments reveal the contribution of genotype, the influence of environment and the effect of their interaction $(\mathrm{G} \times \mathrm{E})$ on the berry transcriptome. Plant J. 2018, 93, 1143-1159. [CrossRef] [PubMed]

50. Pinto, D.L.P.; Brancadoro, L.; Dal Santo, S.; De Lorenzis, G.; Pezzotti, M.; Meyers, B.C.; Pè, M.E.; Mica, E. The influence of genotype and environment on small RNA profiles in grapevine berry. Front. Plant Sci. 2016, 7. [CrossRef] [PubMed]

51. Serra, I.; Strever, A.; Myburgh, P.A.; Deloire, A. Review: The interaction between rootstocks and cultivars (Vitis vinifera L.) to enhance drought tolerance in grapevine. Aust. J. Grape Wine Res. 2014, 20, 1-14. [CrossRef]

52. Carbonneau, A. The Early Selection of Grapevine Rootstocks for Resistance to Drought Conditions. Am. J. Enol. Vitic. 1985, 36, 195-198.

53. Padgett-Johnson, M.; Williams, L.E.; Walker, M.A. Vine water relations, gas exchange, and vegetative growth of seventeen Vitis species grown under irrigated and nonirrigated conditions in California. J. Am. Soc. Hortic. Sci. 2003, 128, 269-276. [CrossRef]

54. Meggio, F.; Prinsi, B.; Negri, A.S.; Simone Di Lorenzo, G.; Lucchini, G.; Pitacco, A.; Failla, O.; Scienza, A.; Cocucci, M.; Espen, L. Biochemical and physiological responses of two grapevine rootstock genotypes to drought and salt treatments. Aust. J. Grape Wine Res. 2014, 20, 310-323. [CrossRef]

55. Corso, M.; Vannozzi, A.; Maza, E.; Vitulo, N.; Meggio, F.; Pitacco, A.; Telatin, A.; D’Angelo, M.; Feltrin, E.; Negri, A.S.; et al. Comprehensive transcript profiling of two grapevine rootstock genotypes contrasting in drought susceptibility links the phenylpropanoid pathway to enhanced tolerance. J. Exp. Bot. 2015, 66, 5739-5752. [CrossRef]

56. Frioni, T.; Biagioni, A.; Squeri, C.; Tombesi, S.; Gatti, M.; Poni, S. Grafting cv. grechetto gentile vines to new $\mathrm{m} 4$ rootstock improves leaf gas exchange and water status as compared to commercial 1103p rootstock. Agronomy 2020, 10, 708. [CrossRef]

57. Galbignani, M.; Merli, M.; Magnanini, E.; Bernizzoni, F.; Talaverano, I.; Gatti, M.; Tombesi, S.; Palliotti, A.; Poni, S. Gas exchange and water-Use efficiency of cv. Sangiovese grafted to rootstocks of varying water-Deficit tolerance. Irrig. Sci. 2016, 34, 105-116. [CrossRef] 
58. Chan, Z. Expression profiling of ABA pathway transcripts indicates crosstalk between abiotic and biotic stress responses in Arabidopsis. Genomics 2012, 100, 110-115. [CrossRef]

59. Rattanakon, S.; Ghan, R.; Gambetta, G.A.; Deluc, L.G.; Schlauch, K.A.; Cramer, G.R. Abscisic acid transcriptomic signaling varies with grapevine organ. BMC Plant Biol. 2016, 16, 1-16. [CrossRef] [PubMed]

60. Ollat, N.; Cookson, S.J.; Destrac-Irvine, A.; Lauvergeat, V.; Ouaked-Lecourieux, F.; Marguerit, E.; Barrieu, F.; Dai, Z.; Duchêne, E.; Gambetta, G.A.; et al. Grapevine adaptation to abiotic stress: An overview. Acta Hortic. 2019, 1248, 497-512. [CrossRef]

61. Delzon, S. New insight into leaf drought tolerance. Funct. Ecol. 2015, 29, 1247-1249. [CrossRef]

62. Lovisolo, C.; Schubert, A. Effects of water stress on vessel size and xylem hydraulic conductivity in Vitis vinifera L. J. Exp. Bot. 2018, 49, 693-700.

63. Tyree, M.T.; Ewers, F.W. The hydraulic architecture of trees and other woody plants. New Phytol. 1991, 119, 345-360. [CrossRef]

64. Gardner, C.M.K.; Robinson, D.; Blyth, K.; Cooper, J.D. Soil Water Content. In Soil and Environmental Analysis: Physical Methods; Smith, K.A., Mullins, C.E., Eds.; Marcel Dekker Inc.: New York, NY, USA, 2001; pp. 13-20.

65. Scholander, P.F.; Bradstreet, E.D.; Hemmingsen, E.A.; Hammel, H.T. Sap Pressure in Vascular Plants: Negative hydrostatic pressure can be measured in plants. Science 1965, 148, 339-346. [CrossRef]

66. De Lorenzis, G.; Rustioni, L.; Parisi, S.G.; Zoli, F.; Brancadoro, L. Anthocyanin biosynthesis during berry development in corvina grape. Sci. Hortic. 2016, 212, 74-80. [CrossRef]

67. Fujita, A.; Soma, N.; Goto-yamamoto, N.; Mizuno, A.; Kiso, K.; Hashizume, K. Effect of Shading on Proanthocyanidin Biosynthesis in the Grape Berry. J. Jpn. Soc. Hortic. Sci. 2007, 76, 112-119. [CrossRef]

68. Reid, K.E.; Olsson, N.; Schlosser, J.; Peng, F.; Lund, S.T. An optimized grapevine RNA isolation procedure and statistical determination of reference genes for real-time RT-PCR during berry development. BMC Plant Biol. 2006, 6, 27. [CrossRef]

69. Livak, K.J.; Schmittgen, T.D. Analysis of Relative Gene Expression Data Using Real-Time Quantitative PCR and the $2^{-\Delta \Delta C T}$ Method. Methods 2001, 25, 402-408. [CrossRef]

70. Hayes, M.A.; Feechan, A.; Dry, I.B. Involvement of Abscisic Acid in the Coordinated Regulation of a Stress-Inducible Hexose Transporter (VvHT5) and a Cell Wall Invertase in Grapevine in Response to Biotrophic Fungal Infection. Plant Physiol. 2010, 153, 211-221. [CrossRef] [PubMed]

71. Lund, S.T.; Peng, F.Y.; Nayar, T.; Reid, K.E.; Schlosser, J. Gene expression analyses in individual grape (Vitis vinifera L.) berries during ripening initiation reveal that pigmentation intensity is a valid indicator of developmental staging within the cluster. Plant Mol. Biol. 2008, 68, 301-315. [CrossRef] [PubMed]

Publisher's Note: MDPI stays neutral with regard to jurisdictional claims in published maps and institutional affiliations.

(C) 2020 by the authors. Licensee MDPI, Basel, Switzerland. This article is an open access article distributed under the terms and conditions of the Creative Commons Attribution (CC BY) license (http://creativecommons.org/licenses/by/4.0/). 